Article

\title{
THE CONCEPTUAL WORLD OF THE GHADARITES
}

\section{RADHA D'SOUZA}

University of Westminster

\begin{abstract}
The Ghadar movement is framed by scholars variously as socialist or protocommunist, anarchist, secular or religious nationalist. These theoretical frames developed in the European historical contexts to oppose liberalism and modernism. Framing historical experiences of colonialism and resistance to it by using theories developed in radically different conditions of European capitalism and Enlightenment, disrupts history-writing and the historical consciousness of people in the Third World. This article examines the historical consciousness that guided Ghadar resistance to colonial rule. How are we to understand the distinction between system and "lifeworld" that Jurgen Habermas makes in a context where the "system" is capitalist/imperialist/ modernist and the "lifeworld" is South Asian/ Indian Enlightenment/ colonial? What was the "lifeworld" of the Ghadar leaders that informed their understanding of nationalism and state, secularism and religion, liberation and justice? Theories contribute to creating historical consciousness and identity by showing us a view of the world that we can identify with, by providing a sense of continuity with the past. Disruption of South Asia's historical consciousness has had profound consequences for the people of the subcontinent. This article locates Ghadar consciousness in the structural transformations of South Asia after the end of the First War of Independence in 1857 known as the Great Ghadar. The paper takes common theoretical lenses used to analyse the Ghadar movement in academic scholarship: secular and ethno-religious nationalism, anarchism and socialism as its point of departure to sketch the theoretical and philosophical routes through which Ghadar leaders arrived at comparable values and political positions. It shows how they could be secular, religious, anarchist and socialist simultaneously. The Ghadar movement is important because it is the last major resistance movement that saw South Asia through South Asian lenses and attempted to address problems of colonialism and national independence in ways that was consistent with Indian historical consciousness and cultural and intellectual traditions.
\end{abstract}

\section{Keywords}

Ghadar movement; historical consciousness; colonialism; social theory; Indic Enlightenment; non-dualism; secularism; federalism; anarchism; socialism; communism; resistance 


\section{Whose History?}

Writing about the Ghadar movement nearly a century and quarter later requires invoking historical memory. Whose memory? Is it the memory of citizens of India, Pakistan and Bangladesh, nation-states that did not exist when the Ghadar movement first began mobilising expatriate South Asian communities in the west coast of the United States and Canada? Is it the memories of the Punjabis, Sindhis, Bengalis, Baluchis, Afghans, Pathans who were (are?) violently torn apart by political fratricide? Is it the memory of Hindus, Muslims, Sikhs competing for claims to state power in a modern "democratic" state? Is it the memory of colonial subjects and their shared experiences of colonial rule defined in terms of the "Other", the coloniser? Is it a universal memory of abstract anticolonialism that privileges the moment of resistance over the historical consciousness that gave rise to the resistance? Whichever history we choose to tell, it can only be done by omitting some aspects of the movement and privileging others.

Historical memory and historical consciousness, writes Rüsen J "welds experiences of the past and expectations of the future" and helps to make sense of the world and our place in it. Historical consciousness, "through individual and collective memory and through recalling the past into the present" achieves identity formation that is necessary to locate ourselves in the world. The passage of identity formation cannot be left to the "natural chain of events" but must be "intellectually comprehended and achieved" (Rüsen 2002, 1-2). "Even a historiography based on methodologically controlled research is determined by the political and social life of its time and by the expectations and dispositions of its audiences" (Rüsen 2002, 3). The disposition of audiences of our times expects historians to help them claim the Ghadar movement variously as Hindu, Sikh, Muslim or secular nationalists, anarchists or communists but rarely as a movement with an alternate vision for South Asia, an alternate modernity anchored to South Asian historical consciousness.

Intercultural approaches to historiography of the Rüsen type that seek to reset universalist European historiography on intercultural foundations, or postmodern approaches that emphasise the specificities and micro-histories of groups and places, simply do not work for societies with colonial histories. Colonialism and imperialism, old and new, disrupt identity formations by sundering relations to locality, place, communities, culture and history. Equally, the theories and practices of scholarly history-writing make it difficult for people to "intellectually comprehend" the experiences of the past and the passage to the future. It is immaterial whether the historian is South Asian or European. The fact remains Indian history has become South Asian history through a temporal passage. The temporal passage fractures the capacities of South Asians to "intellectually comprehend" the past. It challenges historians to write "South Asian" history of India, Pakistan, Bangladesh within nation-state frameworks born from the dim-lit historical passage.

The problem is deeper than establishing an intercultural basis for universal history-writing in the comparative history sense or about researching the empirical specificities of groups, communities and localities. The problem lies with theory building processes and the theoretical 
lenses that come to be ground and polished in the process. Theories also develop under historical conditions. There is, as Ranjan Ghosh argues, an "institutional overpowering" by American (and Western universities more generally), that emanates from the very requirement for "openness, the spirit of reaching out and listening to the voice of the other." This is compounded by the ideal of "modernization" in post-Independence national scholarship (Ghosh, 25). In the geographies of knowledge production since colonialism and imperialism, theories are developed in the colonial imperial centres while (neo)colonies provide the "data" for theorising. There is thus a skewed spatial dialectic in South Asian history-writing that is inbuilt in the theoretical framings.

Theoretical framings of Ghadar history, in the limited scholarship on the subject, view the movement variously as proto-communist, socialist, anarchist, secular nationalist, and religious/ethno (Sikh and Muslim) nationalist. Socialism, anarchism, ethno/religious nationalism and secular nationalism are theories that developed in the European historical context of capitalism. Those theoretical framings come to be extended to South Asian history which was the very antithesis of European capitalism as colonialism, its external dimension (D'Souza 2012). Theories contribute to creating historical consciousness and identity by showing us a view of the world that we can identify with, by providing a sense of continuity with the past. Framing historical experiences of colonialism and resistance to it by using theories developed in a radically different context of European capitalism and European Enlightenment, disrupts history-writing and the historical consciousness of people in the Third World. How then should we recall memories of the Ghadar movement in ways that can enable South Asians to make sense of their world today and help to heal the ruptured historical consciousness?

The sections below explore the problems of theoretical framings the Ghadar movement using modernist theories such as anarchism, ethno/religious nationalism, modern/secular nationalism and communism. These theories developed in opposition to and in engagement with European liberalism. A liberal state is the point of reference, the target of critique for anarchism, socialism, secular and ethno-nationalism. Applying these frameworks in countries with colonial histories presupposes the existence a liberal state and society comparable to Europe and/or reifies liberalism as the normative standard for evaluating state behaviour and deviations from liberal norms. Presupposing liberalism as the normative standard for evaluating British colonialism skews our understanding of the Ghadar "moment" in South Asian history. This article seeks to throw light on that moment by illuminating how the Ghadarites themselves understood their world and how their own understandings of the world as the point of departure disrupts the theoretical frameworks used to analyse the movement. How did they make sense of the world and their place in it? What concepts, theories and intellectual traditions influenced their thinking?

The Ghadar movement marks a cuspal moment in the structural transformations underway in South Asia after the end of East India Company's (EIC) rule. It was a fluid moment of transition from liberal to late imperialism marked by the transition from Company Rule to Crown Rule - i.e. from the East India Company's rule in India to direct rule by the British parliament after the Indian War of Independence in 1857. It was a moment when the ideologies of modernity were emergent and popular consciousness continued to be informed by Indian 
historical consciousness inherited from India's past. What was it in India's past therefore that prompted the Ghadarites to become the most powerful anticolonial, egalitarian and humanist resistance movement? The historical consciousness that guided the Ghadar movement came from a long tradition of humanism and dissent within South Asia, what J.P.S Uberoi calls alternate nondualist modernity (Uberoi 2002, ix). The Ghadarites drew on the alternate non-dualist modernity to challenge colonialism. South Asian Sufism, bhakti, Sikhism amongst others, have a long tradition of internal critique of power and wealth, injustice and oppression within the religious and political establishments that prevailed in the pre-colonial era. This tradition, best articulated by numerous poet-saints, is, what I shall call the Indic Enlightenment. Indic and not Indian because, as already noted, Indian history has transformed into South Asian history through dimlit unenlightened temporal passage that has turned Indian history into South Asian history.

The Indic Enlightenment had its influence across the subcontinent spanning at least four centuries from the twelfth century onwards, extending back to Nizamuddin Auliya (b.1238,Uttar Pradesh d. 1325, Delhi), Sant Kabir (b.1398 Varanasi-d.1518 Maghar), ${ }^{1}$ Guru Nanak (b. 1469 Punjab in Pakistan, -d. 1539 Punjab, Pakistan, founder of Sikhism), Emperor Akbar (1548-1605) (patron of the emerging syncretism in culture and politics), Sant Tukaram (b. 1598 [1608?] - 1649 [1650?]) in Maharashtra, Bulleh Shah (1680 - 1757) in the Punjab, Chokemela (fourteenth century) in Maharashtra, women like Mirabai (b.1498 -d. 1646) in Gujarat, Lal Ded (fourteenth century) in Kashmir, Akka Mahadevi (twelfth century) in Karnataka, to name a few influential figures picked randomly from across the subcontinent and the centuries. The implosion of the Mughul Empire after the death of Emperor Aurangazeb in 1707 opened the way for European traders to intervene amongst various fractions of the imploding empire. In turn the political uncertainties gave rise to numerous Indian thinkers, scholars and social reformers like Shah Waliullah Dehlavi (1703-1762), known variously as the Montesquieu, Gibbon and Vico of South Asia (see Abbott 1962, Amir Khan 2014, Syros 2012), Jyotiba Phule (b. 1827-d. 1890, Maharashtra) as well as political responses like the Satnami movements (late seventeenth century) and the sanyasi-fakir rebellions (mid-eighteenth century). These movements responded to the disintegration of the political order on the one hand and the incursions of the EIC on the other.

These intellectual and political developments had formative influence on the Ghadar leadership. The Ghadar movement is revolutionary because it recognised what is at stake in the emerging modernist colonial knowledge frameworks: the Hindu-Muslim binary leading to ethnocentric nationalism or liberal modernism leading to a rupture with India's past. The Ghadarites turned instead to the Indic Enlightenment drawing on the cultural and historical resources of the poet-saint traditions to mount radical opposition to the atavistic conservative revivalism of religious nationalists on the one hand and the anti-historicism of liberals on the other. They strived to broaden and enrich the Indic Enlightenment by learning from other dissident, egalitarian strands in European intellectual and political traditions, using them to refine their own critique.

\footnotetext{
${ }^{1}$ The birth of Sant Kabir is dated variously between 1398 and 1440 and his death as 1518 to 1540 . He is reputed to have lived a long life.
} 
The sections that follow consider in turn, the attempts to frame the Ghadar movement within antiliberal modernist theoretical frames such as anarchism, socialism and secularism and republican nationalism. The sections illuminate the conceptual world of the Ghadarities and the possibilities of arriving at certain values cherished in the dissident modernist thought through very different theoretical routes. The possibilities of arriving at common political destinations through different theoretical and ideological routes is important if popular politics is to reconnect with historical consciousness of South Asian peoples.

\section{Anarchism, Resistance and Rebellion}

The significant influence of post-colonialism and critical theory has opened up spaces to use anarchism as a theoretical lens to analyse the Ghadar movement (e.g.Oberoi 2009, Ramnath 2011a). British administrators were the first to label the Ghadarites as "anarchists" in 1908 explicitly linking them to Russian anarchists (Heehs 1993, 475). The Anarchical and Revolutionary Crimes Act 1919 (popularly, the Rowlatt Act) incorporated the term anarchism into Indian statute books. The label deflected attention from the injustices of British rule and attributed the causes of resistance to outside in particular, Russian influences. In contrast, in the eighteenth century, when anarchism had not emerged as a competing modernist ideology, resistance to Company Raj was described by administrators variously as "dacoity," "thuggery" and "vandalism." Later day postcolonial scholarship "reversed the gaze" as it were and retrospectively extended to the Ghadar movement the theoretical respectability that anarchism had acquired in critical and radical EuroAmerican scholarship. These post-colonial readings reify the rupture with history, attributing Ghadar historical consciousness to the rise of Russian and Irish anarchism, and like them, with social roots in the peasantry. The readings rely on descriptive and empirical comparisons to theorise the movement in ahistorical ways. This way of reading the movement marginalises preexisting philosophical lenses in Indian political thought and its influence on Ghadar consciousness, privileging instead the influence of Irish, Russian and other anarchists during their brief stays in North America. If the Ghadarites invoked Islamic, Sikh and Hindu texts, history and parables for their inspiration and opposition to colonial rule, their invocations are often seen as idiomatic devices and the uses of cultural vocabulary as mass communication strategy (e.g. Gill 2014; Puri 2012). These frames marginalise and undermine South Asian intellectual and social traditions of resistance in the Indic Enlightenment and the Ghadar leadership's capacities for creative adaption and reinterpretations of Indian concepts and ideas when confronted by modern capitalism and colonialism.

Anarchism as a theoretical lens distracts attention from the philosophical underpinnings of an uninterrupted tradition of secret societies and revolutionary violence against tyranny and injustice in South Asia that had a profound influence on Ghadar thought. These societies were amongst the first to oppose Company Raj after the Battle of Plassey in 1757. By the late nineteenth century there was a revival on a national scale of revolutionary societies engaged in violent political 
actions in Eastern, Western and Northern India. One feature of South Asian societies, J.P.S Uberoi (1994) argues, is that alongside the priestly classes of the brahmins and the mullahs, there has always been widespread presence and active participation of mendicant preachers, jogis, sects, panths, religious societies and associations. These groups, often with their roots in "lower" socioeconomic orders, frequently challenged abuse and misuse of political and priestly power and acted to "check and balance" the exercises of power without aspiring for power. J.P.S Uberoi writes $(1996,16)$,

[...] until we can fully understand the developmental cycle of medieval mendicant orders we cannot place the political phenomena of the 'fighting Jogis' of the sixteenth century and seventeenth centuries, the long contemporary militant struggles of the Islamic Roshaniyya sect (founded by the Bayazid, Pir-I-Roshan, b. Jullundar, 1525), the Satnami revolt of 1675, or the plunder of Dacca in 1763 by the Sannyasis, etc in their proper structural perspective. The analytical paradigm proposed must account under one and the same theory for cases, types or phases of political quietism as well as of political activism and conflict. (italics added).

Movements spearheaded by "fighting jogis", fakirs, Sikh khalsas, jihadists were founded on ontological conceptions about nature, society and people, about internal and external lives, "this" world of economy and politics and "other world" of ontology and cosmology, and about truth, justice and power. In contrast to the Brahmanical priesthood and Islamic clergy, the "fighting jogis", fakirs, sanyasis, sufis, khalsas, panths and jihadists preached the unity of human beings, equality between men, between men and women, social justice, oneness with nature and most importantly, the duty to rebel against oppression and tyranny when it endangered the survival of society and cohesion of social life. It is to these traditions that we need to turn to grasp the synchronic dimensions of "secularism" and "anarchism" in Ghadar thinking - why many amongst them were simultaneously deeply "religious", "secular", "anarchists" and "communists", why so many of their writings were informed by the poetics of the poet-saint traditions, why they affirmed their faith and worked in solidarity with all faiths and non-faiths for a "just cause" to oppose colonial tyranny and oppression. It explains too, the reason why, in contrast to European representations of natives, their opposition to British rule never took on racial, religious and ethnic justifications. In their vitriolic writings against British rule, the reasons to fight the British are never attributed to their race, religion, ethnicity or nationality, but rather to the injustices, tyranny, oppression, betrayal and failed promises of successive British governments.

In South Asia, non-dualism is the dominant philosophical influence. Non-dualist ideas like "unity in duality" (Buddhism), the principle of "non-onesidedness" (anekantavada, Jainism), the unity of the Universe (Sufism), the transient nature of time and place, the interdependent nature of life and non-dualist conceptions of universal and particular, form the basis for diverse influential schools of thought since ancient times (see Ramanujan 1989; Matilal 2004; Barakatullah 1895). 
Sikhism, JPS Uberoi argues, seeks to annihilate the categorical partitions, in particular the divisions between temporal power and spiritual power by "refusing to accept them as separate distinct modes of existence" (Uberoi 1996, 16). Barakatullah writes about Sufi Islam: "the source of multiplicity in the universe is but unity" (Barakatullah 1895, 676). Rebellion and resistance has a very different place in political systems dominated by philosophical non-dualism.

Within non-dualist intellectual traditions, resistance and rebellion are necessary, indeed a duty, when kings and priests deviate from universal ontological realities, when they disrupt the conditions for social life. In South Asian traditions the purpose of rebellion is always to restore the ontological "balance," social cohesion and the authority of just kings and priests. J.P.S Uberoi notes that since Kabir (1440-1580) at least, the poet-saints never preoccupied themselves with questions of power of political or priestly classes. Instead they focused on inculcating in people the centrality of self-rule, autonomy and self-respect (Uberoi 2002, x). When these necessary conditions of social life are violated by kings or priests they must be restored through collective rebellion. As the purpose of rebellion is not to take power and establish alternate power systems, rebellion operates as social corrective. The purpose of rebellion is achieved when conditions for social life are reestablished. Rebellion is about restoring power to its ontological, cosmological, sociological and ethical moorings.

Rebellions to restore the place of human beings in the universe is vastly different from dualist framings of state versus community in anarchism or the anarchist idea of "changing the world without taking power" (see Holloway 2010) where community as well as political and priestly rulers stand as adversaries. Anarchism evidences the adversarial relations of state and community with empirical facts and statistics but remains disconnected from ontological and cosmological conceptions of reality that unifies the adversaries. British administrators in the eighteenth century grasped the place of rebellions in Indian society more clearly than contemporary post-colonial scholars seeking to “decolonise” theory. James Mill, head of the EIC's Examiner's office, a Benthamite, utilitarian thinker, historian, economist, and father of English liberal John Stuart Mill, giving evidence in 1832 before the House of Commons select committee on the affairs of the EIC stated,

The substance of the engagement we make with these princes is this: we take their military protection upon ourselves, and the military power of the state into our own hands. Having taken from them the military powers of the government, that is, all the power, we then say to them, We give up to you the whole of the powers of civil government, and will not interfere with you in the exercise of them. It is well known what the consequences are. [...]: In the ordinary state of things in India, [...], the princes stood in awe of their subjects. Insurrection against oppression was the general practice of the country. The princes knew that when mismanagement and oppression went to a certain extent, there would be revolt, and that they would stand a chance of being tumbled from their throne, and a successful leader of the insurgents put in 
their place. This check is, by our interference, totally taken away; for the people know any attempt of theirs would be utterly unavailing against our irresistible power, accordingly no such thought occurs to them, and they submit to every degree of oppression that befalls them (Court of Directors 1833, 8) (italics added).

The fakir-sanyasi rebellions after the Battle of Plassey in 1757 were the first serious challenges to Company Raj to bring princes and priests back to their ethical moorings as understood in South Asian historical experience. They were by no means the only ones. ${ }^{2}$ Leading members of the Ghadar movement were profoundly influenced by the traditions of revolt and histories of rebellions against oppression, injustices and tyranny in South Asia. They believed it was possible to wean the "stooges of the British" away from the lure of Western liberalism back to Indian sociohistorical anchors. In contrast, the point of departure for anarchism is state oppression where the oppressor state and oppressed communities stand in opposition as adversaries. ${ }^{3}$ The Ghadar call to arms for the defence of the motherland was an attempt to project on the international stage, deep rooted South Asian ideas of universal humanity, cultural pluralism based on ideas of "unity in diversity", justice and the duty to rebel against tyranny always and anywhere.

\section{Socialism, Secularism and Republican Nationalism}

\section{Socialism}

Another modernist framing projects the Ghadar movement as a socialist or protocommunist movement. A common reading of the Ghadar movement is that around the mid-1920s the Ghadarites turned to communist ideology (Puri 2012, 40) perhaps after unsuccessfully trialling European anarchism and syndicalism (see Ramnath 2011b). In understanding Ghadar sympathies for socialist ideology and internationalism there are chronological issues that need straightening. Socialist framings present the socialist movements as antecedent to the Ghadar movement. European theoretical lenses force a linear, sequential relationship between the Bolsheviks and the Ghadarites where the Bolsheviks influenced the Ghadarites. The formative years of the Ghadar movement were between the late nineteenth and early twentieth century. Socialist movements in Europe developed concurrently and parallel to the anticolonial movements (D'Souza 2017).

\footnotetext{
${ }^{2}$ For a general survey of millenarian movements see Stephen Fuchs (1965). On the renunicates led sanyasi-fakir rebellions against the EIC see (Lorenzen 1978). On the Kuka rebellions, the forerunners of the Ghadar movement in the Punjab see (Singh and Singh 1989). For precursors of anti-British movements in Western India see the life and times of Vasudeo Balvant Phadke (b. 1845 Panvel, Maharastra - d. 1883 Aden, Yemen) (Joshi 1959).

${ }^{3}$ A more nuanced analysis of the differences between European anarchism and Indian duty to rebel from intercultural philosophical and historical perspectives must remain a project for the future given the scope of this article. For a review of literature on anarchism see (Adams 2011). For evolution of anarchist thought in contemporary times see (Graeber 2002). On the need for dialogue between postcolonialism and anarchism see (Ramnath 2011a).
} 
Socialism, yet a nascent ideology in Europe, emerged in opposition to European capitalism and its impact on the European social order. India was a colony when the Ghadar movement was born. Until the Second Congress of the Third International held in 1920, the colonial question was a peripheral one for the European socialist movements, focused as they were on European revolutions. In the context of an imploding Russian state after World War I, the shift in the position of the Third International in 1920 came about because of the sustained campaigning and influence of the leadership of anticolonial movements, amongst who the Ghadarites were prominent (Khan and Kamal 2008; Patnaik 2008). Expatriate Indian nationalists like M.N Roy and the Berlin India Committee gave anticolonial readings of Marxism. After the October Revolution when Britain conducted subversive activities in the Central Asian Republics pitting Muslim nations against "atheist communists" (see Russian Administration for Religious Affairs of Russian Moslems 23 May 1923), the Ghadar nationalists played a critical role in mobilising the support of Russia's Central Asian nations for the nascent Soviet state (Ansari 2014; Khan and Kamal 2008; Patnaik 2008). In doing so the anticolonial struggles played their part as important actors in their own right. They succeeded in persuading the nascent Soviet state of the importance of anticolonial movements and the need for the nascent Soviet state to recognise cultural diversity, religious freedoms and the status of different nationalities for the success of socialist project (Ansari 2014; Joshi and Josh 2011 [1992]; Khan and Kamal 2008; Patnaik 2008).

The sequential order of influence conceals two important realities. First, it conceals the fact that there was something else in the intellectual milieu of South Asia that inspired the Ghadarites to confront the British Empire, and to do it with internationalist, humanist and egalitarian orientations building solidarities right across the British empire. Projecting the socialist theoretical frame on the Ghadar movement renders opaque the conceptual world of the Ghadarites. Secondly, the Ghadarites, and Indian nationalists more broadly, also influenced the consolidation of the Bolshevik revolution in the Central Asian Republics comprising Muslim nations with cultural and historical affinities to South Asia. Their influence moderated and adapted socialist thought beyond European and Slavic cultural contexts. The reciprocity of the Ghadar movements was possible precisely because the Ghadar leaders found a uniquely Indic way of understanding communism. The intellectual route to communist ideas is as important as the political support for communist parties and movements. Key elements that explain Ghadar affinities for the Bolshevik revolution were the imperatives of the Indic Enlightenment to eschew, or at least limit acquisition of property and power as the preconditions for community life and collective survival. Inherent in this approach is an inbuilt humanism and egalitarianism. In an interview to the Petrograd Pravda in 1919, Mohammed Barakhatullah, a prominent Ghadarite, reputed Islamic scholar and the first prime minster of the first free Indian government-in-exile in Kabul said,

I am not a communist or socialist... but my political programme at present is the expulsion of the English from Asia. I am an irreconcilable enemy of European capitalism in Asia whose main representative is the English. In this I concur with communists and in this respect we are genuine allies (Khan and Kamal 2008, 9). 
For Barakatullah, capitalism was opposed to Islam. He saw no inconsistency between being a Muslim and a communist if we consider their core values and aims. Both advocate equality, social justice and put community and society at the centre of economic and political life (Barakatullah 1903, 1925 [1924]). Ubaidullah Sindhi, another prominent Ghadarite and the first foreign minister of India's government-in-exile, invoked Islamic texts to insist that Muslim landlords should give up land for redistribution (Anjum 2013, 166). Sikhs inspired by the October Revolution saw no contradiction between their religious beliefs which preached egalitarianism, social justice, and martyrdom and the ideals of communism (Raza 2013, 321). Uberoi (1996) argues that Sikhism made it a duty of Sikhs to resist oppression and tyranny anywhere. Sikhism was successful in undertaking social protest and critical reform because it recognises the world as a reality, negates rich/poor and caste differences, advocates the primacy of community, respect for manual labour, and the duty to defend community by elevating martyrdom against kingdom (Uberoi 1996). These ways of understanding communism must be seen against the wider backdrop where liberal Hindu leaders, drawing on the Bhakti poet-saints, invited attention to the egalitarian traditions in India in the pre-colonial India (see Hawley 2015, ch.1). Hasrat Mohani, a Muslim communist who addressed the first Communist Party of India conference in India in 1925 made a distinction between Indian Communists and Bolsheviks. Bolshevism according to him was one form of communism, there could be other forms and Indians had the right to develop their own variant that was appropriate for Indian cultural and social conditions (cited in Ramnath 2011b, $298 \mathrm{fn}$ 150).

Inspired by the October Revolution, in the aftermath of the bloody suppression of the Ghadar movement during WW1, there was a proliferation of Workers and Peasants parties in different parts of the subcontinent (Joshi and Josh 2011 [1992], chs 3-4). For example, the rump of the Ghadar organisations after their brutal suppression in 1914-15 put their energies into organising the Kirti Kisan party in the Punjab, one of the many workers and peasant parties around the country. These parties were unique in that they were socialist inspired, loosely knit regional political parties with broad social base in the peasantry and urban workers and rooted in local traditions and cultures. The Meerut Conspiracy Case (1929- 1933), Ali Raza (2013) argues, forms a watershed moment for the communist movements in India. The British colonial government brought charges of sedition and subversion against thirty leading communists making explicit links between the emergent communist movement, the Comintern and atheism to discredit the swell of popular opposition to colonial rule that was outside the influence of the state recognised Congress nationalists (see Joshi and Josh 2011 [1992]). Linking atheism and the Comintern (which, in fact, never took any official position on religion) were at the heart of the attempts by the colonial government to discredit the particular form that communism was taking in the subcontinent. The onset of World War II nipped the development of what one might call "pluralist communism" (Joshi and Josh 2011 [1992], Vasudevan 2014). The turn that the communist movements in the subcontinent took later ought not to cloud the moment of theoretical and 
ideological innovation and engagement with modernity that was grounded in the subcontinent's history and intellectual traditions.

\section{Secularism}

Turning to secularism, it is another important theoretical frame for understanding the Ghadar movement and the central plank of Enlightenment liberalism. Secularism in liberal ideology means the separation of institutions of state and religion. European Enlightenment thinkers and bourgeois democratic political movements saw the entwinement of church and state as tyranny and demanded institutional separation of church and state. Enlightenment thinkers went on to challenge the theological basis for politics replacing theology with science and the authority of the church with a non-religious, "secular" state. Neither centralised institutions of religions, nor the entwinement of institutions of religion and state, or the theological justifications for kingship comparable to divine rights existed in pre-colonial Middle East, Persia or Asia. When modern scholars speak of the Ghadar leadership as "secular" or "religious," they refer to the Ghadar commitment to keep religion out of politics. Diverse cultural groups in the subcontinent derived the separation of religion and politics through different intellectual routes. Of these, I refer to the writings of Mohammed Barakhatullah Bhopali not least because he is one of the prominent Ghadarites who has written explicitly on the subject in a pamphlet titled The Khalifet published in 1925 (Barakatullah 1925 [1924]). The pamphlet reveals the intellectual route through which he arrived at his justification for the separation of religion and politics.

Writing in response to the extreme turmoil in the Muslim world that followed the dismemberment of the Ottoman Empire and the occupation of Turkey by Britain, France and Italy, Mustapha Kemal Pasha's abolition of the khalifet, the spiritual seat of Islam after a coup to salvage the Turkish state, and the machinations of the British and French powers to mobilise the Muslim world to set up a puppet khalif at the conferences in Mecca and Cairo, Barakatullah, the erudite Islamic scholar and Ghadarite (Ali 2008; Aslam 2008; Khan 03-10-2010; Khan 2014; Khan and Kamal 2008), anchored his arguments in the historical experiences of Muslim nations. In the pamphlet he highlights a rupture in the history of Muslim nations as a defining moment. The rupture introduces a hiatus between the first three decades of the Islamic commonwealth during the lifetime of Prophet Muhammed and his comrades, and the period after $661 \mathrm{AD}$ when Moaviyah, following the example of Roman emperor Constantine, attempted to subsume the spiritual authority of the khalifet under the temporal authority of kingship (sultanate). Unlike Constantine, Moaviyah was unsuccessful in his endeavour (Barakatullah 1925 [1924], Ch IV). Muslims must acknowledge the historical rupture and what it entails. Acknowledging the turns in their history means Muslims must seek inspiration for democracy, socialism, racial and gender equality, just public administration and property relations from the example of the early Islamic commonwealth during the first three decades of its existence. Grounding his arguments in the historical rupture within Muslim nations, Barakatullah makes three important arguments for the separation of the khalifet from kingship. 
First, Barakatullah argues, the Holy Koran directs that the Islamic community must make appointments to the office of the khalif by consensus. Management of the khalifet and commonwealth of Islam during the first thirty years was based on consultation and consensus which is "the manifestation of liberty, equality and fraternity" (Barakatullah 1925 [1924], 27). It is impossible to appoint khalifs through a consultative process in the contemporary context where there are deep divisions amongst Muslims. Second, no contemporary ruler is capable of defending the lives, livelihoods, property and honour of Muslims, the prime duty of a khalif in the Holy Koran. Therefore, no individual should be burdened with a responsibility that they cannot discharge. Third, and more importantly, he argues,

[T]they [Muslim rulers] are bolstered up by the foreign monetary and military props. So long as they are dependent for their very existence upon such foreign aid they are creatures of a non-Moslem power. If the Shereef [of Medina] be elected as the Khalif, it will amount to this, that up to now the Khailfet had been an engine for the aggrandisement of Islamic despotism and henceforth it will become an instrument for the aggrandisement of a non-Islamic imperialism (Barakatullah 1925 [1924], 57).

The institution of the khalifet could be and ought to be separated from imperialist politics that was everywhere. Intrigues and suspicions were rife, including secret meetings between Gen. Harrington, commander-in-chief of the Allies in Constantinople and the khalif, bribery of the Shareef of Mecca, lobbying in Hejaz, Transjordania, Iraq on behalf of a puppet khalif and much else. Given this context it would be a folly to elect another king as khalif.

What then of other religions and the unity of Hindus, Muslims and Sikhs in their struggle against British colonial rule? Drawing on Koranic verses, Barakhatullah argues that Islam's understanding of truth, justice and righteousness is broad enough to encompass all faiths and schools of thought (Barakatullah 1925 [1924], 16-17). The problem with modern Jews and Christians is that they have cut their moorings from the core principles and teachings of Judaism and Christianity (Barakatullah 1925 [1924], 65) and Muslims must not follow in their footsteps. Transposing the conceptual lens of "secularism" developed in the historical context of Europe to a radically different historical context conceals i) the possibility of arriving at comparable ideas through different intellectual routes; ii) dismisses the historical consciousness that informed the Ghadar movement as irrelevant; iii) dismissing the intellectual history of the Ghadar movement disempowers contemporary South Asians from the theoretical and conceptual tools needed to address contemporary problems, in particular the uses of religion by imperial powers to reinforce imperial domination. 


\section{Republican Nationalism}

In a similar vein, greater caution is necessary before unproblematically projecting modernist ideas of nationhood, particularly federalism and republicanism, on to the Ghadar movement. Language becomes the first challenge in translating from one conceptual world to another. We have some insights into Ghadar ideas of democracy, federalism and republicanism from the writings of Ubaidullah Sindhi who drafted an alternate constitution for free India in 1922/1924 as the convenor of the Mahabharat Sarvarajiya Party translated as All India People's Republican Party. Whether sarvarajya, literally "all states" can be translated as the antimonarchical concept of "republicanism" is questionable (cf Ramnath 2011b). Copies of Sindhi's proposed constitution were proscribed in India and confiscated by the British government (Anjum 2013, 165). Ubaidullah's The Constitution of the Federated Republics of India outlined a social and political vision for the subcontinent that is radically different from the constitutions that came to be adopted by India, Pakistan and Bangladesh after partition and independence. Given the fissiparous politics that continues to challenge the subcontinent, Ubaidullah's vision has continued significance.

Rejecting the settler-state model of federalism in the United States, Canada and Australia and the ethno-nationalist model of European nation-states, Ubaidullah insisted that the cultural diversity of the subcontinent must be the basis of a new confederation of the nations of the subcontinent (Shahjahanpuri 1995, appendix). ${ }^{4}$ Ubaidullah recognised that diversity within India cuts across religious, linguistic and cultural lines such that it was not possible to speak of a unified Muslim or Hindu nation, nor was it possible to eliminate regional and cultural differences (Khan 2013). Ubaidullah remained a vocal opponent of partition of the subcontinent as well as the centreprovincial relations in the administrative reforms introduced by the colonial government. Ubaidullah's constitution for India does not emulate the American federal system as critics and sympathisers alike have claimed. Instead it proposes a democratic and anti-imperialist constitution that recognises the diversity of the subcontinent (Anjum 2013; Khan 2013).

Ubaidullah's ideas of a confederation of Indian republics modernised South Asian concepts of "quom" and "watan." "Quom" is a difficult word to translate into English. What is pertinent is that a quom is a historically constituted community that may or may not be affiliated to territory. Watan, translated as "homeland" denotes affinity to place of one or several quoms. In the European idea of nation-state, historically evolved nations were co-terminus with defined territories. The hyphenated nation-state recognises the authority of the modern institution of statehood to represent the historically evolved European nations. In contrast, in South Asia, a quom may or may not belong to a defined territory and many quoms may share a common watan or territorial homeland. A confederation of quoms as self-governing republics with India or Hindustan as their shared watan or homeland was thus both an adaptation of ideas of republicanism, federalism and

\footnotetext{
${ }^{4}$ A copy of the constitution is appended to Shahjahanpuri's book. Another version of the draft constitution is appended in (Shaikh 1986).
} 
nationalism and an advancement of those ideas in the context of colonialism and imperialism. The multiple and varied relations between nations and homelands meant, historically, identities in South Asia were fluid and plural. Barakatullah describes his identity in the following way, "I belong to two circles of equal size, but which are not concentric. One is India, and the other is the Muslim world...We as Indian Muslims came in both circles. We belong to these two circles, each of more than 300 millions, and we can leave neither" (quoted in Khan 2014, 62).

\section{The Conceptual World of the Ghadarites}

The Ghadar movement was a response to the aftermath of the 1857 war or the Great Ghadar and takes its name after it. In the five to six decades following the 1857 war, social relations were, as Eric Stokes writes, "decisively modified by economic action" (Stokes 1970, 117). The Ghadar movement was a response to those changes. The Ghadar movement was the single biggest challenge to the British Empire after 1857. Equally, the 1857 war was the last of the traditional resistance movements (Stokes 1970, 48). The Queen's Proclamation of 1858 made peace with native princes, the educated Indians, the landlords and merchants. To the Indian princes it promised an end to territorial annexations, to the educated Indians it promised equal opportunities in the civil services and public services, to the merchants and landlords it promised new opportunities in trade and commerce and recognition of traditional privileges. Against the soldiers and peasants direct Crown Rule unleashed horrific state violence (D'Souza 2014a). The events of 1857 shook the confidence of the British in Indian soldiers and created the spectre of soldiers and peasants joining forces. In 1873 Alfred C. Lyall, the home secretary to the Government of India described the situation that awaited British administrators in these words: "you are treading upon fires hidden under deceitful ashes" (Wagner 2013, 170). As late as 1894 the British press continued to carry alarming news reports of intelligence failures and the possibility of having to re-conquer India for a second time (Wagner 2013).

In the aftermath of the Great Ghadar of 1857, economic centralisation became the organising principle of imperial administration under direct Crown rule. Economic centralisation, a key logic of a unified colonial state after the end of Company Raj was a radical break from the decentralised economic architecture with long and deep historical roots in South Asian society. Ghadar leaders grew up in the shadows of the most intrusive and direct legal and technological interventions in those social structures. The post-1857 British government established a centralised intelligence apparatus prompted by the fact that the 1857 war had taken the EIC administration by surprise (Popplewell 1995). The highly discriminatory Vernacular Press Act 1877 and Arms Act, 1878 became synonymous with the new repressive state apparatus. The most far reaching structural change in the governance of India following the 1857 war was the reorganisation of the army on ethnic/religious lines under the centralised command and control of the colonial state (Barkawi 2012). 
The Ghadar movement, with roots amongst the soldiers and peasants, sought to overcome the institutionalisation of social divisions without denying religion, race or ethnic identities because the cultural resources were available to them. The poet-saints of the Indic Enlightenment composed their social philosophy in verse that could be sung by anyone precisely because their audiences were the marginalised and oppressed peasants, artisans and soldiers (D'Souza 2014b). The Ghadarites were not demanding "freedom of religion" that the Queen's Proclamation promised but rather recalling a social order that existed prior to EIC rule where religious differences did not impede economic, political and social intercourse between diverse social groups. This explains why they could be religious and communists simultaneously. In that precolonial order armies were affiliated to land and people and raised from amongst them by local leaders, for example the polygars (e.g. see Dua 1974) in the south, the killedars in the west (e.g. see Dispatch from Lieut-gen Sir T. Hislop 1820) and the faujdars established under Akbar's reign (e.g. see Siddiqui 1967). The polygars, killedars, faujdars and others of the old order were at the heart of the 1857 war against the EIC. Crown rule reorganised the army on ethnic lines by disestablishing traditional roles and sources of recruitment for the armies. The new imperial norms transferred the loyalties of soldiers from place and people to a central foreign authority through a system of employment contracts and army pensions. For the soldiers these changes introduced a deep schism in their ethical and moral universe, what Farish Noor (2011) calls a "bipolar relationship". The British demanded loyalty to contracts with the state whereas their communities and cultures demanded loyalties to people and place (quom and watan). This schism produced paradoxical results. It divided Hindu, Muslim and Sikh communities, especially in the Punjab, into those who rallied for the Ghadar cause against British rule and those that rallied to fight Britain's wars, from the Boer Wars to World War II. ${ }^{5}$

For the Ghadarites, the 1857 war was not a distant historical memory. They grew up in the shadows of its aftermath and were shaped by it. After the British retook control of India, guerrilla actions continued well into the 1860s (Stokes 1970) and fed into the rise of a new militant nationalist movement of which the Ghadar in the North, the Swarajists in the east and west are leading examples. The agitations against land colonisations in the Punjab under the Punjab Colonisation of Land Act, 1893 and the Punjab Land Alienation Act, 1900 were led by men who were to become prominent leaders of the Ghadar movement, most notably Ajit Singh, Sufi Amba Prasad and Lal Chand Falak (Kaur 2011). Ajit Singh was exiled to Burma's infamous Mandalay prison, the very same prison where Bahadur Shah Zaffar, the last Mughul emperor of India was imprisoned for his role in the 1857 war. On his release, with a second arrest warrant awaiting him, Ajit Singh escaped to Europe where he worked to organise expatriate Indians (see Pal 1992). There were others like him.

\footnotetext{
${ }^{5}$ Letters from soldiers on missions during World War I speak of their anguish over betraying the British after "eating their salt" (namak harami), the "salt" being state pensions (see Omissi 1999).
} 
Representative democracy did not come to the subcontinent wearing the robes of universalism and secularism and waving liberty, equality and fraternity as its flag. It came wearing robes of economic rivalries masquerading as ethno/religious nationalism fanned by communal electorates to divide and conquer with the full connivance and participation of the landlords, merchants and what the British called the "educated classes." The Ghadar movement opposed these reforms as a "sell-out." The landlord and merchant classes and the "educated classes" engaged with the new opportunities open to them within the confined racialised, communalised spaces in the new state structures. Religion and class interests elided in the new forms of politics articulated in the new language of European Enlightenment (see Gilmartin 1991; Smith 1968). The types of ideological justifications and engagements that the new structural changes set in motion have become the points of departure for theoretical framings of the past, present and future of the subcontinent, in theory and political practices ever since. Whatever the value of these frames for subsequent understandings of South Asia, they could not have been the main influence and inspiration for the Ghadar movement participants. The new ways of representing Indian society in the language and vocabulary of European Enlightenment by the "educated classes" and a dehistoricised atavistic religious vocabulary by the landlord and merchant classes reversed core ideas of the Indic Enlightenment.

\section{Conclusion}

Jurgen Habermas makes an analytical distinction between "system" as preconfigured modes of coordination, e.g. the bureaucracy, markets, money, institutions and "life world" as the shared cultural systems of meanings acquired from being members of a society (Habermas 1984). The pertinent question in relation to the Ghadar movement is this: how are we to understand the distinction between system and "lifeworld," if at all, in a context where the "system" is capitalist /imperialist/ modernist and the "lifeworld" is South Asian/ Indic Enlightenment/ anticolonial? What was the "lifeworld" of the Ghadar leaders that informed their understanding of nationalism and state, secularism and religion, liberation and justice? Whereas their actions were directed at modern colonialism, their frames of reference for ethical action, the essence of politics, was formed by Sikh, Sufi, Bhakti and other dissident world views as articulated by the poet-saint traditions in the subaltern social histories in Punjab, Sindh and Northwest regions of the subcontinent. The Ghadar opposition to imperialism interweaves two strands of thought therefore: one modern about political power entailed in ideas of secularism, republicanism, democracy, egalitarianism and such and another traditional, the ethical and moral basis for political action as articulated in the philosophical and intellectual traditions of Indic Enlightenment led most prominently by the poet-saints of the subcontinent.

The Ghadarites expanded the scale of critique in radical South Asian traditions and projected them on an international plane against colonialism. The internationalisation of the South Asian critical intellectual traditions mirrors the internationalisation of South Asian army and bureaucracy under colonial rule. That those traditions should have resonances or overlaps with 
traditions of dissent and humanism in European intellectual traditions should not mislead us into hemming the movement within European theoretical straightjackets. The tendency to see the Ghadar movement within religious frames or European modernity writes-out five centuries of egalitarian, pluralist and humanist traditions in society, politics, philosophy and literature in the subcontinent. Using European categories and theories to frame Indian realities limits our understanding of the extent to which the Ghadar movements drew on the Indic Enlightenment to address contemporary problems presented by colonial oppression. Furthermore, it precludes the development of theories that advance the premises of the Indic Enlightenment in ways that are consistent with South Asian historical consciousness and capable of addressing contemporary problems. Without an intercultural vocabulary, modern historiography is forced to "squeeze" the ontological, philosophical, methodological and historical premises of Ghadar historical consciousness into a frame that makes it possible to attribute radically different orientations to the movement variously as secular and/or religious nationalism, or socialist and/or anarchist.

In The Jewish Question, a canonical text on the secular state, Marx argues that the secular state is an abstraction devoid of particularities of conflicting class, religion and race that characterise civil society (Marx 1987 [1843]). British rule introduced liberal discourses of religious freedoms first proclaimed in the Queen's Proclamation of 1858 but institutionalised religious identities into the very heart of the constitutional order and colonial institutions - the state, the army, education and communal electorates as representative government. The colonial state was, thus, the opposite of Marx's abstract, universal state standing in binary opposition to myriad competing interest-driven groups constitutive of civil society.

Superimposing theoretical frames that developed in European historical conditions on Indian realities introduces artificial categorical dualisms that are alien to South Asian "lifeworld." The dissident traditions in South Asia, founded on non-dualism as the dominant philosophy, emphasise the essential unity of the world that underpins diversity and plurality. The structural transformation that followed the repression of the 1857 war and later the Ghadar movement in 1914-15 introduced all manner of categorical partitions in the theoretical frames to interpret and understand South Asian society with disastrous political consequences that ruptured politics from history. The Ghadar movement is perhaps the last important movement in South Asia that saw the problems of the subcontinent through Indic lenses and attempted to address problems of colonialism and national independence in ways that was consistent with Indian historical consciousness and cultural and intellectual traditions.

\section{References}

Abbott, Freeland. 1962. "The Decline Of The Mughul EmpireE And Shah Waliullah." The Muslim World 52 (2):115-123. 
Adams, Matthew S. 2011. "The World That Never Was: A True Story of Dreamers, Schemers, Anarchists and Secret Agents/New Perspectives on Anarchism, Labour and Syndicalism: The Individual, the National and the Transnational/Anarchism and Moral Philosophy/Post-Anarchism: A Reader." European Review of History: Revue européenne d'histoire 18 (5-6):851-856.

Ali, Prof. Abdul. 2008. "Role of Maulana Barakatullah in the Freedom Struggle of India." In The Contribution of Raja Mahendra Pratap and Prof. Barakatullah Bhopali in Freedom Struggle and its Importance in Contemporary Society, edited by M. Hassan Khan and Ayisha Rais Kamal, 15-22. Kolkatta: Towards Freedom; Maulana Abdul Kalam Azad Institute of Asian Studies, Kolkatta.

Amir Khan, Shahid. 2014. "Displacement of Shal Walliullah's Movement And Its Impact On Northern Indian Muslim Revivalist Thoughts." Journal of the Research Society of Pakistan $51(2)$.

Anjum, Tanvir. 2013. "A Voice from the Margins: An Appraisal of Ubaid-Allah Sindhi"s Mahabharat Sarvrajia Party and its Constitution." Journal of Political Studies 20 (1):159177.

Ansari, Humayun. 2014. "Maulana Barkatullah Bhopali's Transnationalism: Pan-Islamism, Colonialism, and Radical Politics." In Transnational Islam in Interwar Europe, edited by Umar Ryad and Gotz Nordbruch, 181-209. New York: Palgrave Macmillan.

Aslam, Juhi. 2008. "Life History of Maulana Barakatulla Bhopali." In The Contribution of Raja Mahendra Pratap and Prof. Barakatullah Bhopali in Freedom Struggle and its Importance in Contemporary Society, edited by M. Hassan Khan and Ayisha Rais Kamal, 36-44. Kolkatta: Towards Freedom; Maulana Abdul Kalam Azad Institute of Asian Studies, Kolkatta.

Barakatullah, Mohammed. 1895. "Islam and Soofeeism." Westminster Review Jan 1852-Jan 1914 144 (July 1895):674-678.

Barakatullah, Mohammed. 1903. "Islam and Democracy." ARENA XXX (3):256-267.

Barakatullah, Mohammed. 1925 [1924]. The Khilafet. 2nd ed. London: Luzac \& Co.

Barkawi, Tarak. 2012. "Army, Ethnicity and Society in British India." In The Indian Army in the World Wars, edited by Kaushik Roy, 419-443. Leiden; Boston: Brill. 
Court of Directors, East India Company. 1833. Minutes of Evidence Taken Before the Select Committee of the House of Commons on the Affairs of the East-India Company, February 28th to July 9th, 1832 VI Political or Foreign London: J L Cox and Son,.

D'Souza, Radha. 2012. "Imperial Agendas, Global Solidarities and Socio-legal Scholarship on the Third World: Methodological Reflections" Osgoode Hall Law Journal 49 (3):6-43.

D'Souza, Radha. 2014a. "Revolt and Reform in South Asia: Ghadar Movement to 9/11 and After." Economic \& Political Weekly (Special Articles) XLIX (8):59-73.

D'Souza, Radha. 2014b. "What Can Activist Scholars Learn from Rumi." Philosophy East and West $64(1): 1-24$.

D'Souza, Radha. 2017. "Victor's Law?: Colonial Peoples, World War II And International Law." International Comparative Jurisprudence 3 (1):67-84.

Dispatch from Lieut-gen Sir T. Hislop, Bart. G.C.B., to the Governor-gen in Council, dated Sept 10, 1819. 1820. "Papers Relating to the Killedar of Talmeir." The Asiatic Journal and Monthly Register for British India and its Dependencies 10 (July-December):55-60.

Dua, J.C. 1974. "Nature of the Poligar Revolts in the Ceded Districts During the First Half of the Nineteenth Century: A Case Study." Proceedigs of the Indian History Congress, 35rd Session Nagpur 234-244.

Fuchs, Stephen. 1965. Rebellious Prophets: A Study of Messaianic Movements in Indian Religions. Bombay: Asia Publishing House.

Ghosh, Ranjan. "Institutionalised Theory, (In)fusion, Desivad." Oxford Literary Review:25-36.

Gill, Parmbir Singh. 2014. "A Different Kind Of Dissidence: The Ghadar Party, Sikh History And The Politics Of Anticolonial Mobilization." Sikh Formations 10 (1):23-41. doi: 10.1080/17448727.2014.890800.

Gilmartin, David. 1991. "Democracy, Nationalism and the Public: A Speculation on Colonial Muslim Politics." South Asia: Journal of South Asian Studies 14 (1):123-140.

Graeber, David. 2002. "The New Anarchists." New Left Review 13:61-73. 
Habermas, Jurgen. 1984. The Theory of Commuicative Action. Translated by Thomas McCarthy. Vol. 1. Boston: Beacon Press.

Hawley, John Stratton. 2015. A Storm of Songs: India and the Idea of the Bhakti Movement. Cambridge, Massachusetts; London, England: Harvard University Press.

Heehs, Peter. 1993. "Terrorism in India During the Freedom Struggle." The Historian 55 (3):469482.

Holloway, John. 2010. Change the World Without Taking Power. London: Pluto Press.

Joshi, Shashi, and Bhagwan Josh. 2011 [1992]. Struggle for Hegemony in India: A History of the Indian Communists Vol 1: The Irrelevance of Leninism. New Delhi: Sage.

Joshi, V.S. 1959. Vasudeo Balvant Phadke: First Indian Rebel Against British Rule. Bombay: D.S. Marathe.

Kaur, Harwinder. 2011. "'History' In Popular Movements : British Punjab, 1849-1947." PhD, Department of History, Faculty of Social Sciences, Punjabi University Patiala (17BZFS(M)88).

Khan, Ayub. 03-10-2010. "Mawlana Barakatullah: An Indian Muslim Revolutionary in America." The Muslim Observer, accessed Access date 02/10/2016. http://www.ilmgate.org/mawlana-barakatullah-an-indian-muslim-revolutionary-inamerica/.

Khan, M. Hassan, and Ayisha Rais Kamal, eds. 2008. The Contribution of Raja Mahendra Pratap and Prof. Barakatullah Bhopali in Freedom Struggle and its Importance in Contemporary Society. Kolkatta: Towards Freedom; Maulana Abdul Kalam Azad Institute of Asian Studies, Kolkatta.

Khan, Mohammed Ayub. 2013. "His Master's Voice?: Ubayad Allah Sindhi's Re-interpretation of Orthodox Islam as Inclusive Revolutionary Ideology." In Interpreting Ghadar: Echoes of Voices Past Ghadar Centennial Conference Proceedings October 2013, edited by Satwinder Kaur Bains, 99-116. Abbotsford, BC, Canada: Centre for Indo-Canadian Studies University of the Fraser Valley.

Khan, Mohammed Ayub. 2014. "Universal Islam: The Faith And Political Ideologies Of Maulana Barakatullah 'Bhopali' " Sikh Formations 10 (1):57-67. doi: 10.1080/17448727.2014.888246. 
Lorenzen, David N. 1978. "Warrior Ascetics in Indian History." Journal of the American Oriental Society 98 (1):61-75.

Marx, Karl. 1987 [1843]. "On the Jewish Question." In David McLellan: Karl Marx Selected Writings. Oxford: New York: Toronto Oxford University Press.

Matilal, B K. 2004. Logical and Ethical Issues: An Essay on Indian Philosophy of Religion New Delhi: Chronicle Books.

Noor, Farish A. 2011. "'Racial Profiling' Revisited: The 1915 Indian Sepoy Mutiny in Singapore and the Impact of Profiling on Religious and Ethnic Minorities." Politics, Religion \& Ideology 12 (1):89-100. doi: 10.1080/21567689.2011.564404.

Oberoi, Harjot. 2009. "Ghadar Movement and Its Anarchist Geneology." Economic \& Political Weekly (Special Articles) 44 (50):40-50.

Omissi, David. 1999. Indian Voices of the Great War: Soldiers' Letters, 1914-1918. Houndsmill, Basingstoke, Hampshire: Macmillan Press.

Pal, Savinder. 1992. "Activities of Sardar Ajit Singh Abroad." The Panjab: Past and Present XXVIII (52):54-60.

Patnaik, Dr. Ashok Ku. 2008. "Raja Mahendra Pratap and Prof. Barakatullah in USSR - The Beginning of a New Socio-Economic Understanding." In The Contribution of Raja Mahendra Pratap and Prof. Barakatullah Bhopali in Freedom Struggle and its Importance in Contemporary Society, edited by M. Hassan Khan and Ayisha Rais Kamal, 4-14. Kolkatta: Towards Freedom; Maulana Abdul Kalam Azad Institute of Asian Studies, Kolkatta.

Popplewell, Richard J. 1995. Intelligence And Imperial Defence: British Intelligence and the Defence of the Indian Empire 1904-1924. London: Frank Cass.

Puri, Harish. 2012. Ghadar Movement to Bhagat Singh: A Collection of Essays. Chandigarh, Punjab: Unistar Books.

Ramanujan, A.K. 1989. "Is There An Indian Way of Thinking? An Informal Essay." Contributions to Indian Sociology 23 (41):43-58. 
Ramnath, Maia. 2011a. Decolonizing Anarchism: An Antiauthoritarian History of India's Liberation Struggle. Edinburgh, UK: A.K Press.

Ramnath, Maia. 2011b. Haj to Utopia : how the Ghadar movement charted global radicalism and attempted to overthrow the British empire. Berkeley, Calif. ; London: University of California Press.

Raza, Ali. 2013. "Separating the Wheat from the Chaff: Meerut and the Creation of "Official" Communism in India." Comparative Studies of South Asia, Africa and the Middle East 33 (3):316-330.

Rüsen, Jörn. 2002. "Introduction: Historical Thinking As Intercultural Discourse." In Western Historical Thinking: An Intercultural Debate, edited by Jörn Rüsen, 1-11. New York; Oxford: Berghahn Books.

Russian Administration for Religious Affairs of Russian Moslems. 23 May 1923. Proclamation to All Muslims in the World. In Seventeen Moments in Soviety History: An Online Archive of Primary Sources. http://soviethistory.msu.edu/1921-2/the-muslim-east/the-muslim-easttexts/proclamation-to-all-moslems-in-the-world/.

Shahjahanpuri, Abu Salman. 1995. Maulana Ubaidullah Sindhi Ke Inquilabi Mansube. Lahaur: alMahmud Ikaidami.

Shaikh, Muhammed Hajjan. 1986. Maulana Ubaid Allah Sindhi: A Revolutionary Scholar. Islamabad: National Institute of Historical and Cultural Research.

Siddiqui, Noman Ahmad. 1967. "Pulls and Pressues on the Faujdar Under the Mughuls." Indian History Congress, Proceedings of the 29th Session, Patiala.

Singh, Nahar, and Kirpal Singh, eds. 1989. Rebels Against the British Rule: Guru Ram Singh and the Kuka Sikhs. New Delhi: Atlantic Publishers and Distributors.

Smith, Ray T. 1968. "The Role of India's "Liberals" in the Nationalist Movement, 1915-1947." Asian Survey 8 (7):607-624. doi: 10.2307/2642630.

Stokes, Eric. 1970. "Traditional Resistance Movements and Afro-Asian Nationalism: The Context of the 1857 Mutiny Rebellion in India." Past \& Present (48):100-118. 
Syros, Vasileios. 2012. "An Early Modern South Asian Thinker on the Rise and Decline of Empires: Shāh Walī Allāh of Delhi, the Mughals, and the Byzantines." Journal of World History 23 (4):793-840.

Uberoi, J. P. S. 1994. "The elementary structure of medievalism: religion, civil society and the state." Contributions to Indian Sociology 28 (1):1-34.

Uberoi, J.P.S. 1996. Religion, Civil Society and State: A Study of Sikhism. Delhi: Oxford University Press.

Uberoi, J.P.S. 2002. The European Modernity: Science, Truth and Method. New Delhi: Oxford University Press.

Vasudevan, Hari. 2014. "Asiatic Orientations of Early Soviet Socialism: A perspective on the Life and Times of Maulana Azad." Indian Historical Review 41 (2):271-295.

Wagner, Kim A. 2013. "'Treading Upon Fires': The 'Mutiny'-Motif and Colonial Anxieties in British India." Past \& Present 218 (1):159-197. 